\title{
A BETTER EDUCATION THE GREAT NEED OF THE PROFESSION.
}

The lawyer is evermore the leader in society; and by society I do not mean that little coterie which lives simply to dine and wine, but that larger association of all individuals whose mingled labors have achieved the present, and will work out the future of human life and destiny. In society, in this better sense of the term, the lawyer is the leader.

Temporarily, it is true, he may be displaced by the soldier. In the abnormal and chaotic movements which accompany revolution and war the lawyer is ignored. Inter arma leges silent. The man on horseback becomes the leader, and around his life there is a pyrotechnic splendor which has lifted him into undue prominence, and made him too frequently the central figure in written history. But his leadership is always temporary, and conditioned upon some disarrangement of the normal condition of human society. When life is moving on in peaceful and regular lines the soldier drops to his appropriate place, as simply the representative of force-the one ready to help the lawyer as the true leader in all efforts which make for the bettering of human life and the coming in of a higher civilization.

So, in the early days of New England, the minister, for a while, superseded him. Legislation denounced him, and society under its theocratic leadership endeavored to forbid his presence, and exclude him from recognition. Washburn, in his Judicial History of Massachusetts, says:

"It was many years after the settlement of the colony, before " anything like a distinct class of attorneys at law was known.

"And it is doubtful if there were any regularly educated attor-

"neys who practiced in the courts of the colony during its 
" existence. Lechford, it is true, was here for a few years, but he

" was soon silenced, and left the country. Several of the magistrates

" had also been educated as lawyers at home, among whom were

"Winthrop. Bellingham, Humfrey, and probably Pelham and

"Bradstreet. But these were almost constantly in- the magis-

" tracy, nor do we hear of them ever being engaged in the man-

"agement of causes. If they made use of their legal acquire-

"ments, it was in aid of the great object which they had so much

" at heart-the establishment of a religious commonwealth, in

"which the laws of Moses were much more regarded as prece-

"dents than the decisions of Westminster Hall, or the pages of

"the few elementary writers upon the common law which were

" then cited in the English courts."

It is curious to note some of the legislation aimed to dispossess the lawyer from his rightful position, and exclude him from even existence in society. In 1656 the following statute was enacted in that colony: "This court, taking into consideration the great "charge resting upon the colony, by reason of the many and "tedious discourses and pleadings in the courts, both of plaintiff " and defendant, as also the readiness of many to prosecute suits " in law for small matters. It is therefore ordered, by this court "and the authority thereof, that when any plaintiff or defendant "shall plead by himself or his attorney, for a longer time than "one hour, the party that is sentenced or condemned shall pay "twenty shillings for every hour so pleading more than the com" mon fees appointed by the court for the entrance of actions, to " be added to the execution for the use of the country." There was a crafty wisdom in this statute which commends itself to any one of much experience on the bench, and I venture to suggest that a similar act would to-day be sustained by every court. By an act passed in $\mathrm{r} 66_{3}$, "usual and common attorneys" were excluded from seats in the General Court, as the Massachusetts Legislature was called. But notwithstanding these efforts it soon developed that the needs of society were stronger than the wishes of the theologic advisers, and little by little the lawyer was lifted in even that theocratic society into his proper and accustomed place, and there, as elsewhere in the land, became the recognized leader.

To-day, wealth is striving to dispossess him from his position of leadership, and money is used to secure position and control, but with the ordinary result that place and power acquired alone by such means simply expose the possessor to ridicule and scorn. It takes something more than a $\$ 200$ silk nightshirt to make a 
man a leader in social forces, and whatever of prominence and notoriety money may purchase, it never purchases the power to change the currents of life.

This leadership of the lawyer is not accidental nor enforced, but natural and resulting from his relations to society. That which binds society together and makes possible its successes and its blessings, is the mystic force which we call "law." It is that which transforms humanity from a mere aggregation of individuals, each by his own strong arm asserting his rights, into an organized society, the rights of whose individual members, as against one another, are enforced by the united strength of all, and in whose consequent freedom of personal action has been wrought out all the achievements of the past, and rest all the possibilities of the future. He, therefore, who voices the law, who is its interpreter, must inevitably stand in the front as the leader in the social organization, the one to direct the movement of all its uplifting forces. Sneer at it as any one may, complain of it as any one will, no one can look at American society as it is to-day, and has been during the century of national existence, without . perceiving that the recognized, persistent and universal leader in social and political affairs, has been the gentleman of the green bag. A distinguished member of our profession said to me the other day in Nashville: "It is a curious fact that though there is no express authority therefor in any constitution or statute in the land, the lawyers have always been the rulers of this nation." We speak of our constitution as the wise organic instrument under whose provisions the nation has moved on to strength and glory, but that constitution was the handiwork of lawyers. They framed it, and they have interpreted it. Think how we should have drifted, and what a helpless mass of people we should have been without its grants, limitations and distributions of power. And, in a general way, the same may be said of every State Constitution, and of every statute. It is the brain of the lawyer which fashions them, and his brain that applies and makes them useful. As a general rule, made more conspicuous even by the few brilliant exceptions, the lawyer has been the legislator, the judge, and the executive.

The power which alone permanently controls and lifts upward is brain power, and brain power applied in such a way and to such forces as regulate life in its daily action. Leadership, however, does not attend on the mere name of lawyer. It will continue in him and become more or less potent as his capacity therefor improves or wanes, according to his increasing or lessening 
fitness for interpreting the rules of hiuman conduct and directing the movements of society. There is no physical force to compel his supremacy. He has no inherited right, and he must always stand intellectually in front if be would lead. Civilization lifts all men up. The schoolroom places each man on a higher level than his father occupied. Knowledge is not only more widely distributed, but also moving on a higher plane. And the lawyer of the future, to continue the leader, must be a wiser man than the lawyer of the past or present.

The thought of some is to dispossess the lawyer by giving to each man a knowledge of the rules of law, and you will find on many bookshelves such volumes as these: "Every Man His Own Lawyer," "The Business-Man's Guide,"-books aimed to place before all men the common rules for interpreting and controling business transactions. Some fancy that with this diffusion of knowledge the need for the lawyer will cease. They who indulge in such fancy forget the fact that the many never keep pace with the few, that social and business relations become more complicated as civilization advances, and that with the complexity of those relations comes a multiplicity of rules and laws beyond the reach of the ordinary education of the many. There is as much difference between the few primitive rules that controlled society in its early stages of development and those which are now required for the management of its great and interlaced interests, as there is between the hatchet, the saw and other ordinary tools of the carpenter, and the marvelous and intricate machinery of our great manufacturing establishments. It may require but little time and effort to learn how to use a plane or a hand-saw, but to construct and keep in motion and order all the involved machinery of a great manufacturing establishment requires years of patient study and careful attention. So it may be that a little knowledge will enable one to go into a primitive society and advise as to the rules of law controlling its few transactions, but he who would stand in one of our great commercial cities as a power and a leader, advising and directing all its multiform affairs, must be a man of superior knowledge and large wisdom.

We hear many suggestions to-day as to the means necessary to make the law keep pace with the needs of advancing society. Law reform is a great cry. Simplicity in mode of procedure is thought by some to be the one thing needful. Far be it from me to belittle this demand. I do not wonder that the lawyer fell into disrepute when the highest effort seemed to be put forth in solving mere questions of pleading and practice, when the pride of 
the lawyer was in tripping his adversary through a mere technicality, and when the outcome of too many a law suit was not the determination of the relative rights of the litigants but simply how nearly the pleadings on the one side or the other conformed to a technical and arbitrary system. Chief Justice Taney, writing of his professional experience, says: "In that day strict and nice technical pleading was the pride of the bar, and I might also say of the court. And every disputed suit was a trial of skill in pleading between counsel, and a victory achieved in that mode was much more valued than one obtained on the merits of the case." I am glad that law reformers have swung ponderous blows against the common law system of pleading and practice, and are striving to give the utmost simplicity to modes of procedure. Once in a while we see one of those technical devotees of ancient ways, whose delight is simply in the maneuvers of the court room. I remcmber one, who, employed to defend a chancery suit, wearied the court by the multitude of his dilatory, evasive, and technical pleas and motions. Finally, the judge, in his impatience, said to him, "Why do you take up my time with these frivolous and technical matters; why do you not come to the merits of the case at once?" and his reply, which illustrates so well the spirit of the old practitioners, was, "the moment I get to the merits of the case I lose all interest in it." No thoughtful man can doubt that simplicity in modes of procedure is of the utmost importance. The mere tools of the profession should be easily handled. Writing a pleading, or any other document, in a dead language is not the best evidence of the highest practical learning, or the greatest capacity. And it is to the credit of our profession that its members are rapidly coming to appreciate this truth; to realize that mere form is of trifling moment, and that substance of right and justice is the one thing to be striven for. God speed the day when a victory won by a trick shall ruin the lawyer who wins it.

Again, another demand is for more speed in the despatch of litigation A slow procedure with free right of appeal from court to court and abundant license of indirect collateral attack was barely tolerable when life itself moved slowly, when business transactions were few, when travel was by canal boat or stage coach, when the mail was weekly or at best tri-weekly, and when leisure was abundant. The pure gold of truth and justice was finally separated, it is said, after being sifted through many judicial sieves. "Jarndyce $v$. Jarndyce" expressed even then the contempt of thoughtful minds. The law's delay became proverbial. 
Now, when travel is by steam, and correspondence by electricity, when business transactions challenge the seconds in their flight, when men grow rich or poor in a fortnight, and all life moves in the hot haste of a Kansas cyclone, something must be done to bring the movements of the courts into harmony with the speed of other things. It is not strange that business men are compelling the members of their various commercial bodies to settle their controversies through committees rather than by law suits. Lawyers are proverbially conservative, and they do not change their habits or notions as easily or as quickly as some might wish. Precedent is an awful tyrant in our profession. What has been is to many the sacred law of what must be, and an iconoclast on the bench is a sacrilegious judicial monster. Even that tribunal of the nine black gowns glories in the past, and follows in its traditions, and the agonizing cry of the despondent dissenter, even in the income tax case, is that stare decisis is being stabbed in the house of its friends. Et tu Brute! When the court had little to do, the justices were wont to spend the morning hours of each Monday in reading at length what they had written during the prior weeks. What has been must be, and so, although the great stress of accumulating business demands every hour, the customs of the past still largely control. Some one has denounced in language too strong for me to quote the waste of time in reading to an audience of roo or so that which is the interpretation of the law for $70,000,000$ of people, who learn what has been decided not from the lips of the justices but from the pages of the press. And, I may add, the acoustic properties of the court room are so imperfect, and the voices of the justices generally so low, that scarcely half the scanty audience hear what is said. And when one speaks so that all in the room do chance to hear, the press dispatches announce to the world that the audible justice has made a stump speech from the bench. But "great is Diana of the Ephesians," and so for "about the space of two hours" every Monday morning the reading must go on.

Yet speed of itself may be more of a vice than a virtue. Important questions are not rightly decided unless fully considered, and the administration of justice would soon be pronounced a mockery if first impressions controlled every case. But greater expedition can be obtained without detracting from fullest examination and consideration. Shorten the time of process. Curtail the right of continuance. When once a case has been commenced deny to every other court the right to interfere, or take jurisdiction of any matter than can be brought by either party into the 
pending litigation. Limit the right of review. Terminate all review in one appellate court. Reverse the rule of decision in appellate courts, and instead of assuming that injury was done if error is shown, require the party complaining of a judgment or decree to show affirmatively not merely that some error was committed in the trial court, but also that if that error had not been committed the result must necessarily have been different. It may be said that this would make reversals difficult to obtain. They should be difficult. The end of litigation should be almost always in the trial court. Business men understand that it is best that the decisions of their committees of arbitration should be final and without any review; while some of our profession seem to think that justice is more likely to be secured if by repeated reviews in successive courts, even to the highest in the nation, the fees of counsel can be made to equal if not exceed the amount in controversy between the clients. In criminal cases there should be no appeal. I say it with reluctance, but the truth is that you may trust a jury to do justice to the accused with more safety than you can an appellate court to secure protection to the public by the speedy punishment of a criminal. To guard against any possible wrong to an accused, a board of review and pardons might be created with power to set aside a conviction or reduce the punishment, if on the full record it appears not that a technical error has been committed, but that the defendant is not guilty, or has been excessively punished.

The truth of it is, brethren: in our desire to perfect a system of administration, one which shall finally extract from confused masses of facts and fictions the absolute and ultimate verities, we forget that tardy justice is often gross injustice. We are putting too heavy burdens on our clients, as well as exhausting the patience of the public. Better an occasional blunder on the part of a jury or a justice of the peace, than the habit of protracted litigation.

The idea of home rule and local self-government is growing in favor. Thoughtful men more and more see that the wise thing is to cast upon each community full responsibility for the management of its local affairs, and that the great danger to free government is in the centralization of power. Is it not in line with this thought that as far as possible the final settlement of all controversies which are in themselves local shall be by the immediate friends and neighbors of the litigants? Was not that the underlying thought of the jury as first established? And while we boast that the jury system is the great bulwark of our liberties, are we 
not in danger of undermining its strength and impairing its influence by the freedom of appeals? Is not the implication therein that the jury and the trial judge cannot be trusted, and is not the sense of responsibility taken away from both when they understand that no matter what they may decide some superior and supposedly wiser tribunal is going to review all their decisions and correct whatever of mistake they may make?

We boast of the educating influence of the ballot-box, and say that only as each citizen realizes that the responsibilities of government rest upon him is possible the development of a perfect system of popular government. Is it not also true that the jury room has its educating influence, and that we ought so to adjust our system of jurisprudence that each juror shall come to feel that the responsibility for the administration of justice rests largely upon him?

But whatever of help may be in these suggested reforms, they are impotent of themselves to create the leader. They are simply a matter of machinery. The power must be in the man. The lawyer must be fitted to lead. For that a thorough education is necessary. And so I come to the thought which I wish to impress upon you; and that is: if our profession is to maintain its prominence, if it is going to continue the great profession, that which leads and directs the movements of society, a longer course of preparatory study must be required. A better education is the great need and the most important reform. The door of admission to the bar must swing on reluctant hinges, and only he be permitted to pass through who has by continued and patient study fitted himself for the work of a safe counselor and the place of a leader.

I do not propose to discuss the different methods of legal education, or compare the law school with the office, the case with the text-book. These are questions which others can and doubtless will discuss with far more ability and with the benefit of a larger experience. That which I wish alone to emphasize is the need of securing in some way to every one admitted to practice the benefit of a preparation therefor far surpassing that which most young lawyers now enjoy. I speak with the utmost freedom, for I did that which I now condemn. I hastened through my legal studies and was by the diploma of a law school and a certificate from a court declared fit to advise as to all rights and liabilities, and to carry on any litigation before I was old enough to be entrusted with the right to vote. I appreciated the mistake when I attempted to practice, and I fear some of my clients became equally aware of the fact. 
But why is a higher education to-day the special need of the profession? Because, first, the law is a more intricate and difficult science than heretofore. The very complexities of our civilization and the multiform directions of human enterprise have not only increased the number but have also given greater variety to the rules controlling business transactions. He who would become qualified to counsel and guide must therefore have a larger legal lore, and that is only obtained by a more extended study and training. While it is true that the practice of the law is becoming divided into specialties, and we have the insurance lawyer, the railroad lawyer, etc., yet no man can bécome a successful specialist without a general knowledge of the rules obtaining in other departments than his own.

Because, second, to preserve the confidence of the community in the profession, each member must be qualified for the higher demands now made upon it. When society perceives that the great number are but slightly educated, how soon will the lawyer fall into disrepute. He will be only the object of the sneer of the cynic and the laugh of the wit. He will be thrown from his position of leader, and no longer sought after, respected, or followed.

Because, third, his mistakes are freighted with greater possibilities of injury. When business transactions are nothing more than an occasional barter of a chattel, or a simple contract for labor, a mistake works but little injury, and only to a few. But when they involve the great railroad and commercial dealings, so common to-day, a mistake may be fruitful of large and widespread ruin. So the responsibilities which rest upon us are greater than ever before, and we must rise to the level of those responsibilities, or both we and the society we attempt to lead will suffer.

Because, fourth, society each day of its advancing civilization needs and demands a wiser leadership. The welfare of humanity rests not on what has been accomplished, but on the steps forward which it takes. If those steps are wisely advised and prudently taken, then we may confidently look for the coming in of the day of which poets have sung, and which prophets have foretold, when peace and righteousness shall fill the earth. While, on the other hand, if illy advised and rashly taken, progress ceases and society resolves itself again into the anarchy and chaos from which it has so slowly arisen. It has often been said that a community is no better than its leaders, and while there may be temporary exceptions, that is certainly the general rule. So if we would have a 
steady advance in social order we must have an equally constant advance in the character and accomplishments of the lawyers, its leaders.

I know that mere education is not all-sufficient. There must be a man to be educated. It is an old saying that you cannot make a silk purse out of the caudal appendage of the female swine. No more will any amount of study and training pour legal lore into some craniums or give that rare and blessed gift, common sense. Still that does not prove that there is no need of education. Henry Ward Beecher once said that dress does not make the man, but when the man is made he looks a great deal better dressed up. So while mere study will not supply the lack of legal capacity, given one capable of becoming a lawyer, and a thorough education will place him in the front.

The strength of an army is not in its numbers, but in its discipline and training. Cortez, with a handful, rode through thousands of opposing Mexicans and entered the capital city in triumph. Japan's disciplined troops saw scarcely anything else than the backs of the fleeing Chinese, and the most numerous people on the face of the earth were conquered within a.few weeks. So it is with our profession. Its power lies not in the mere number of its members, but in their learning and capacity. A single true and noble lawyer is strength and glory, while a thousand pettifoggers are weakness and shame. In our late war, with its millions of volunteer soldiers, who became the victorious leaders? The trained students of military science. Their education had fitted them to lead. The great movements of civilized society upwards are struggles, though not wars. Who can lead in those movements? Mainly the trained lawyers, they whose long study of human rights and obligations enables them to place before each individual the limits of action, and to guide into paths of life and conduct, which are ways of pleasantness and paths of peace, and so the paths through which civilization moves on and up.

It may be objected that if the course of study is extended and the conditions of admission to the bar increased a great many will be deterred from entering the profession. A perfect answer is that a great many ought to be deterred. A growing multitude is crowding in who are not fit to be lawyers, who disgrace the profession after they are in it, who in a scramble after a livelihood are debasing the noblest of professions into the meanest of avocations, who instead of being leaders and looked up to for advice and guidance, are despised as the hangers-on of police courts and the 
nibblers after crumbs which a dog ought to be ashamed to touch. Even of those who would love to keep up the dignity of the profession many find no adequate compensation from the practice, and so mingle with it dealing in insurance, real estate, and kindred matters, to eke out the living the law does not furnish. It would be a blessing to the profession, and to the community as well, if some Noachian deluge would engulf half of those who have a license to practice. Webster's reply to the question whether the profession was not crowded was that the first story was full but that there was plenty of room in the second. We should see to it that there be no first story, and that only second-story lawyers be found on our rolls.

It is said that some of the noblest of our members would be shut out from the law and turned into other pursuits. If a four years' course of study had been required, would Abraham Lincoln have become a lawyer? My reply is two-fold. First, seldom would any one capable of becoming a hero of the bar be turned away. Obstacles only stimulate the efforts of such men. They work their way up in spite of all difficulties. They glory in their ability to overcome all opposition. Secondly, if perchance some one worthy of a place on our rolls should he kept away there will be plenty left. The general level of professional standing should not be lowered for fear some single chieftain is never found.

Finally, it is objected that the high standard should not be insisted upon, because in our hamlets and smaller villages there is room for very ordinary lawyers. This is a mistake. There is no place anywhere on the face of the earth for a cheap lawyer. It is true that in a village there may be but little business, true that many transactions are of such a simple character that a limited knowledge of the law will guide one safely through them; but it is also true that the relations between the villages and the great business cities are becoming more and more intimate, and are such that often the highest legal lore is required to properly advise the dwellers in the former as to their rights, duties and liabilities, and so the lawyer in the village must be qualified to meet the lawyer in the city on equal terms. Further, he will represent the village in the Legislature, and he should be able to make that village a power in the legislation of the State. There should be a general lifting up of the profession so that all its members everywhere be recognized as leaders.

The final peace of the world will be wrought out through our profession. I know the poet sings of the day

"When the war drum throbs no longer and the battle flags are furled In the parliament of man, the federation of the world.". 
But the poet is mistaken. The legislator will not bring the day of universal peace. There will never be one great parliament, one Federal reptrblic embracing all races and ruling the world. The law of race individuality with its consequent differences and antagonisms cannot be overcome. Gaul and Teuton, Slav and Saxon will never become one people. Blood is thicker than water. Because individuals of these varied races come to this new land of ours and dwelling as neighbors are slowly moving towards one homogeneous people, it does not follow that the law of race will ever be forgotten or ignored in the native land. The vision of one great nation with a single parliament is only a poet's dream. But the lawyer will work out the final peace and bring in the glad day when the spear shall be turned into a plowshare and the sword into a pruning hook, and nations shall learn war no more. In each separate nation as it advances in civilization more and more are differences settled and rights adjusted by the lawyer and the judge, rather than by the pistol and bowie-knife; so as the world advances in civilization will differences between nations be in like manner settled. Arbitrations are growing in favor, and international courts will soon be a part of the common life of the world. I know the time may seem far distant when any such court shall come into existence. It will be witness to a great advance in civilization, and yet within the last fortnight I have seen it stated in the papers that the French Assembly has unanimously passed a resolution looking to the establishment of some tribunal of arbitration to settle all differences that may in the future arise between that nation and this country. The world is becoming familiar with international arbitrations, and the settlement of disputes thereby ; and every successful arbitration is but a harbinger of the day when all disputes between nations shall be settled in courts of peace and not by the roar of cannon and waste of blood.

When in youth I studied the structure of our government, I looked with awe and reverence upon the Supreme Court of the United States, a tribunal taking no cognizance of the minor disputes between individuals within the several States, but sitting in judgment upon the weightier controversies between States and citizens thereof, and determining the rights and liabilities of States to each other and to citizens. I thought of the solemn sense of responsibility which must rest upon each justice thereof as he came to the decision of every case. The years have brought me to a place on that bench. With a profounder reverence and a personal sense of responsibility I now look upon that court and its work, and I would that every judgment it pronounces should be 
wrought out with such wisdom as through the long stretch of coming years to stand the supremest test.

Does it tell of the coming on of second childhood, or is it proof of a growing confidence in man and his capacity for self-control that I now look with the full assurance of faith to the dawning of a day when some great international court shall come into being, whose judgments, touching no questions between individuals. shall determine all controversies between nations, and by such determinations bid the world's farewell to the soldier? But by whom shall such a tribunal be established, and who is to sit therein and render the judgments which shall command such confidence and respect that willing obedience thereto be yielded by all ? Out of the rich brain of our profession shall be wrought the form and structure of that court, its fashion and its glory, and the lawyers shall be the judges thereof.

So believing, let us all strive to lift the standard of professional character and acquirements so that no one shall ever think of challenging our place in the front.

David J. Brezuer.

[By permission of the American Bar Association.] 